\title{
Mouse lymphatic endothelial cell targeted probes: anti-LYVE-I antibody-based magnetic nanoparticles
}

This article was published in the following Dove Press journal:

International Journal of Nanomedicine

20 June 2013

Number of times this article has been viewed

\section{Qiu Guo ${ }^{1,2, *}$ \\ Yi Liu',* \\ $\mathrm{Ke} X \mathrm{u}^{\prime}$ \\ Ke Ren' \\ WenGe Sun'}

'Department of Radiology, The First Hospital of China Medical University, Shenyang, Liaoning, People's Republic of China; ${ }^{2}$ Key Laboratory of Imaging Diagnosis and Interventional Radiology of Liaoning Province, Shenyang, Liaoning, People's Republic of China

*These authors contributed equally to this work
Correspondence: Ke Xu; Yi Liu Department of Radiology, The First Hospital of China Medical University, Shenyang, Liaoning, I I000I, People's Republic of China

Tel +862483282447

Fax +86248328 2629

Email kexu@vip.sina.com;

liuli00I6@Yahoo.com.cn
Purpose: To investigate the specific targeting property of lymphatic vessel endothelial hyaluronan receptor-1 binding polyethylene glycol-coated ultrasmall superparamagnetic iron oxide (LYVE-1-PEG-USPIO) nanoparticles to mouse lymphatic endothelial cells (MLECs).

Methods: A ligand specific target to lymphatic vessels was selected by immunohistochemical staining on the sections of a Lewis subcutaneous transplanted tumor. The z-average hydrodynamic diameter (HD), zeta potential, and the relaxivity of PEG-USPIO and LYVE-1-PEG-USPIO nanoparticles were determined with a laser particle analyzer and magnetic resonance $T_{2}$ spin echo sequence, respectively. Prussian blue staining and transmission electron microscopy (TEM) of nanoparticle labeled cells were performed to determine the nanoparticles' binding form. Magnetic resonance imaging (MRI) was performed in vitro to evaluate the signal enhancement on the $T_{2}$ spin echo sequence of the nanoparticle labeled cells. The iron content of the labeled cells after the Prussian blue staining and MRI scanning was determined by atomic absorption spectroscopy (AAS).

Results: The anti-LYVE-1 antibody was used as the specific ligand to synthesize the target probe to the MLECs. The mean z-average HDs of the LYVE-1-PEG-USPIO and PEG-USPIO nanoparticles were $57.42 \pm 0.31 \mathrm{~nm}$ and $47.91 \pm 0.73 \mathrm{~nm}$, respectively, and the mean zeta potentials of the LYVE-1-PEG-USPIO and PEG-USPIO nanoparticles were $12.38 \pm 4.87 \mathrm{mV}$ and $2.57 \pm 0.83 \mathrm{mV}$, respectively. The relaxivities of the LYVE-1-PEG-USPIO and PEGUSPIO nanoparticles were $185.48 \mathrm{mM}^{-1} \mathrm{~s}^{-1}$ and $608.32 \mathrm{mM}^{-1} \mathrm{~s}^{-1}$. Cells binding nanoparticles were visualized as blue granules in the Prussian blue staining. The TEM results of the labeled cells showed the specific localization of nanoparticles. The AAS results of labeled cells after the Prussian blue staining and MRI scanning showed that the LYVE-1-PEG-USPIO nanoparticles had good binding selectivity for MLECs. MRI results indicated that the PEG-USPIO and LYVE-1-PEG-USPIO nanoparticles could generate contrast on $\mathrm{T}_{2}$-weighted imaging, and the correlation between $\mathrm{R}_{2}$ and the iron content of the labeled cells was significantly positive.

Conclusion: This study demonstrated that LYVE-1-PEG-USPIO nanoparticles might potentially be used as an MRI contrast agent for targeting MLECs, and the magnetic properties of LYVE-1-PEG-USPIO nanoparticles were suitable for MRI.

Keywords: nanoparticles, lymphatic vessel endothelial hyaluronan receptor-1 (LYVE-1), ultrasmall superparamagnetic iron oxide (USPIO), mouse lymphatic endothelial cells (MLECs), magnetic resonance imaging (MRI)

\section{Introduction}

The lymphatic system is essential for the maintenance of tissue fluid homeostasis. With tumor growth, intratumoral pressure will gradually increase, mainly as the result of mechanical pressure generated from the proliferation of tumor cells and the perfusion 
pressure of intratumoral microvessels. Thus, intratumoral lymphatic vessels may become an important decompression pathway, enabling the outflow of interstitial fluid and tumor cells and their migration to other regions. ${ }^{1,2}$ Many studies have shown that there is a relationship between malignant tumor metastases and increased density of intratumoral lymphatic vessels. ${ }^{3-6}$ Most of these results come from the immunohistochemical staining of intratumoral lymphatic vessels in sections of tumor specimens, and the specific biomarkers used for lymphatic vessels are several proteins, which are expressed in lymphatic endothelial cells (LECs), such as the mucin-type transmembrane protein Podoplanin, ${ }^{7}$ lymphatic vessel endothelial hyaluronan receptor-1 (LYVE-1), ${ }^{8}$ homeobox transcription factor Prox-1, ${ }^{9}$ and vascular endothelial growth factor receptor-3 (VEGFR-3). ${ }^{10-12}$

Although the in vitro method is the current gold standard for the study of intratumoral lymphatic vessels, the occurrence and development of lymphatic vessels cannot be dynamically observed. Meanwhile, theoretically, the contrast agents of computed tomography (CT) and magnetic resonance (MR) injected intravenously could enter the tumor stroma, and drain into the tumor lymphatic vessels, and finally flow back into the venous system, so that the intratumoral lymphatic vessels could be imaged. However, it is difficult to distinguish between the intratumoral blood vessels and intratumoral lymphatic vessels due to the simultaneous imaging of them. With the emergence and rapid development of molecular imaging, this could make it possible to image intratumoral lymphangiogenesis in vivo with specific targeted probes, ${ }^{13-15}$ and provide a direct method to evaluate the biological characteristics of intratumoral lymphatic vessels. However, this is on the condition that high sensitivity probes and high resolution imaging equipment are acquired.

Because of its high spatial resolution, noninvasiveness, and ability to provide anatomic and physiologic information simultaneously, MR imaging (MRI) is widely used in molecular imaging, such as MR in vitro cell imaging and MR in vivo imaging of small animals. Ultrasmall superparamagnetic iron oxide (USPIO) nanoparticles with higher sensitivity can improve the contrast enhancement effect by decreasing the $\mathrm{T}_{2}$ - and $\mathrm{T}_{2}{ }^{*}$-weighted relaxation time of tissues. ${ }^{16}$ However, for most in vivo applications, nanoparticles need to overcome the nonspecific phagocytosis by mononuclear phagocyte system (MPS). One strategy to decrease nonspecific phagocytosis is to modify the nanoparticles with polyethylene glycol (PEG). ${ }^{17}$ PEG can also form steric barriers to the agglomeration that aid in particle dispersion. So, a specific antibody to lymphatic vessels should be chosen, which is then used to bind with polyethylene-coated USPIO (PEG-USPIO) nanoparticles.

Like many other markers used in molecular pathology, none of the LEC-associated molecule markers is entirely specific for LECs. Due to the transient expression in the nucleus, prox-1 is difficult to use for clinical applications. ${ }^{18-20}$ Although VEGFR-3 expresses in LECs, it lacks lymphatic vessel specificity in cancer because it also expresses in blood vessel epithelium. ${ }^{21}$ LYVE-1 is specially expressed in LECs, and does not exist in blood vessel epithelium, except in normal liver blood sinusoids, spleen endothelium, high endothelial venules, and activated tissue macrophages. ${ }^{22-25}$ Podoplanin is a specific marker of the LECs and is not expressed in blood vessel epithelium, ${ }^{26}$ but it is expressed in the epithelium of the choroid plexus, ${ }^{27}$ kidney podocytes, ${ }^{28}$ and the lung is a major site of podoplanin expression. ${ }^{29}$

In this study, first, we selected a relatively specific ligand between the anti-LYVE-1 antibody and anti-podoplanin antibody by immunohistochemical staining on the sections of a Lewis subcutaneous transplanted tumor, then used it to synthesize the molecular targeted probe. The physical characteristics of the probe were analyzed, including particle size, zeta potential, and relaxivity. Prussian blue staining, transmission electron microscopy (TEM), and atomic absorption spectrometry (AAS) of the labeled cells were performed to determine whether mouse LECs (MLECs) could be specifically and efficiently identified by this probe.

\section{Material and methods \\ Establish Lewis tumor model}

To establish the Lewis tumor mouse model, $1.0 \times 10^{6}$ Lewis tumor cells (purchased from AiBiological Research, Shanghai, People's Republic of China) in $100 \mu$ L of Roswell Park Memorial Institute (RPMI)-1640 medium were inoculated subcutaneously in the right armpit region of ten 6-weekold male BALB/c mice (provided by the Laboratory Animal Center of our university, the First Hospital of China Medical University). Our study was approved by the institutional animal care committee of our university.

\section{Immunohistochemistry}

When the tumor volume grew to about $1 \mathrm{~cm}^{3}$, the tumorbearing mice were executed with overdose anesthesia. The tumors were removed from the right armpit of the mice, fixed with $4 \%$ paraformaldehyde for 24 hours, paraffin-embedded, and serial $5 \mu \mathrm{m}$ thicknesses were cut. Immunostaining with the anti-LYVE-1 antibody and anti-podoplanin antibody were described in a previous report. ${ }^{30}$ Sections were deparaffinized, 
rehydrated, and pretreated with $3 \% \mathrm{H}_{2} \mathrm{O}_{2}$ for 20 minutes to block endogenous peroxidase activity. The following primary antibodies were used: hamster monoclonal anti-mouse podoplanin antibody (1:200, ab11936; Abcam, Cambridge, UK), rat monoclonal anti-mouse LYVE-1 antibody (1:100, MAB2125; R\&D SYSTEMS Inc, Minneapolis, MN, USA), biotinylated anti-hamster immunoglobulin $\mathrm{G}(\mathrm{IgG})(1: 100$, ab6782; Abcam), and biotinylated anti-rat IgG (1:100, ZB2307; ZSGB-BIO, Beijing, People's Republic of China). The slides were incubated with the anti-LYVE-1 antibody and anti-podoplanin antibody overnight at $4{ }^{\circ} \mathrm{C}$, then treated with biotinylated secondary antibodies followed by incubation with horseradish peroxidase-conjugated streptavidin at room temperature for 30 minutes. Diaminobenzidine (DAB) was used as the chromogen. The slides were counterstained with hematoxylin.

\section{LYVE-I-PEG-USPIO and PEG-USPIO nanoparticles}

The PEG-coated USPIO nanoparticles (PEG-USPIO) and PEG-USPIO coupled with rat monoclonal anti-mouse LYVE-1 antibody (MAB2125; R\&D SYSTEMS Inc) (LYVE-1-PEG-USPIO) nanoparticles were provided by The Institute of Chemistry, Chinese Academy of Sciences (Beijing, People's Republic of China). For the LYVE-1PEG-USPIO nanoparticles, the feed ratio of the anti-LYVE-1 antibody to the PEG-USPIO nanoparticles was 6:1.

\section{Z-average hydrodynamic diameter (HD) and zeta potential measurement}

The z-average HD and zeta potential of two types of nanoparticles were measured with a laser particle analyzer (Nano ZS90; Malvern Instruments, Malvern, UK), the two types of nanoparticles were diluted with double distilled water ( $\mathrm{pH}$ 6.0) and put into a sample chamber; the temperature was $25^{\circ} \mathrm{C} \pm 0.05^{\circ} \mathrm{C}$.

\section{Relaxivity of LYVE-I-PEG-USPIO and PEG-USPIO}

LYVE-1-PEG-USPIO and PEG-USPIO agarose gel suspensions ( $1 \%$ agarose gel) were prepared with iron concentrations of $0,0.0017,0.0034,0.0068,0.0136$, and $0.0272 \mathrm{mM}$ in $0.25 \mathrm{~mL}$ Eppendorf tubes. For the MR measurements, these tubes were embedded in a tank filled with $1 \%$ agarose gel to avoid interference produced by macroscopic external magnetic field $\mathrm{B} 0$ inhomogeneities. MRI was performed by using a 3.0 T MRI scanner (Signa HDxt imager; GE Healthcare Bio-Sciences Corp, Piscataway, NJ, USA) equipped with a small animal coil provided by GE. Imaging was achieved by using the $\mathrm{T}_{2}$ spin echo sequence. The parameters were as follows: repetition time $(\mathrm{TR})=4000 \mathrm{~ms}$; echo time $(\mathrm{TE})=10$, $20,40,60,80$, and $100 \mathrm{~ms}$; field of view $(\mathrm{FOV})=8 \times 8 \mathrm{~cm}^{2}$; matrix size $=256 \times 256$; slice thickness $=1 \mathrm{~mm}$; number of excitation $(\mathrm{NEX})=3$. Source images analysis was made on a GE ADW4.4 workstation. $\mathrm{A} \mathrm{T}_{2}$ map program was used to calculate the sample $T_{2}$ relaxation times, and based on the $\mathrm{T}_{2}$-relaxation time, the relaxation rate $\left(\mathrm{R}_{2}\right)$ was calculated as the inverse of the $\mathrm{T}_{2}$-relaxation time in seconds $\left(1 / \mathrm{T}_{2}\right)$. Each Eppendorf tube's axial section was measured at three regions of interest (ROIs) $(3 \times 4$ pixels $)$ in at least three layers.

\section{Cell culture}

MLECs (purchased from AiBiological Research) were the primary culture cell line (to keep the homology, MLECs were used). Colon 26 tumor cells (provided by the Kanazawa University School of Medicine, Kanazawa, Japan) were the cell line of mouse colon tumor that we used. MLECs were grown and maintained according to the vendor's recommendation using Dulbecco's modified eagle medium (DMEM; Life Technologies, Carlsbad, CA, USA) supplemented with $10 \%$ fetal bovine serum (FBS; Life Technologies) and antibiotics (1\% penicillin/streptomycin; Life Technologies). Colon 26 tumor cells were propagated in RPMI-1640 medium (Life Technologies) supplemented with 5\% FBS and antibiotics. Cells were maintained under standard conditions of $37^{\circ} \mathrm{C}$ and $5 \% \mathrm{CO}_{2}$ and the passage numbers of all cells were between three and nine.

\section{Immunofluorescence microscopy}

In order to determine the expression of LYVE-1 receptor in MLECs and colon 26 cells, immunofluorescence was performed. MLECs and colon 26 tumor cells were grown to confluence on six-well plates (BD Biosciences, Franklin Lakes, NJ, USA), fixed with 4\% paraformaldehyde for 20 minutes at room temperature followed by permeabilization with $0.3 \%$ TritonX-100 for 5 minutes. Cells were incubated with a blocking solution containing $5 \%$ bovine serum albumin-phosphate buffered saline with Tween for 1 hour at room temperature, and then treated with primary antibody (rat monoclonal anti-mouse LYVE-1 antibody, 1:20, MAB2125; R\&D SYSTEMS Inc) and secondary antibody (goat anti-rat IgG/fluorescein isothiocyanate, 1:100; ZSGB-BIO). Nuclei were stained with DAPI (1023626001; Roche, South San Francisco, CA, USA). Specimens were examined via a Nikon TE2000-S inverted microscope (Nikon Corporation, Tokyo, Japan) equipped with a Spot-RT digital camera. 


\section{Prussian blue staining for labeled cells and corresponding AAS}

To demonstrate the label efficiency of LYVE-1-PEG-USPIO and PEG-USPIO nanoparticles, MLECs were plated at $1 \times 10^{5}$ cells $/ \mathrm{mL}$ on each well of the six-well plates in $2 \mathrm{~mL}$ serum-free DMEM (Life Technologies), colon 26 cells were plated at $1 \times 10^{5}$ cells $/ \mathrm{mL}$ on each well of the six-well plates in $2 \mathrm{~mL}$ serum-free RPMI-1640 medium (Life Technologies), cultured at $37^{\circ} \mathrm{C}$ with $5 \% \mathrm{CO}_{2}$ and $100 \%$ humid atmosphere for 16 hours, and then either LYVE-1-PEG-USPIO or PEG-USPIO nanoparticles were added at two different concentrations ( 25 and $100 \mu \mathrm{g} \mathrm{Fe} /$ $\mathrm{mL}$ ) for 2 hours at $37^{\circ} \mathrm{C}$ with $5 \% \mathrm{CO}_{2}$ and $100 \%$ humid atmosphere, in $2 \mathrm{~mL}$ DMEM or RPMI-1640. Unlabeled MLECs and colon 26 cells were used as control groups. After 2 hours of incubation, the supernatant was removed, and the labeled and unlabeled MLECs and colon 26 cells were washed three times with phosphate-buffered solution (PBS) to remove nanoparticles that were free in solution or loosely adhered to the cell surfaces. Cells were fixed with $4 \%$ paraformaldehyde for 30 minutes and then washed three times with PBS. Prussian blue staining was performed by incubating fixed cells in a mixture of $10 \%$ potassium ferrocyanide and 10\% hydrochloric acid (Shanghai Yuanye Biological Technology Co, Shanghai, People's Republic of China) for 30 minutes, followed by washing with PBS, and counterstaining with eosin. Cells were photographed under a Nikon TE2000-S inverted microscope. Cells exhibiting blue particles were considered Prussian blue-positive. After being photographed, the labeled cells of each sample were harvested from the six-well plates separately by using a cell scraper and resuspended in $1 \mathrm{~mL}$ double distilled water for measuring the iron content of the labeled and unlabeled cells with AAS (Z2000, Hitachi Ltd, Tokyo, Japan). The experiment was performed three times.

\section{TEM}

MLECs and colon 26 cells were detached from the cell culture flasks using $0.05 \%$ trypsin (Life Technologies), and adjusted to a concentration of $1 \times 10^{5}$ cells $/ \mathrm{mL}$ in growth media. Then $2 \mathrm{~mL}$ of the cell suspension was plated on each well of the six-well plates at $37^{\circ} \mathrm{C}$ with $5 \% \mathrm{CO}_{2}$ and $100 \%$ humid atmosphere for 16 hours. After incubating with two kinds of nanoparticles at $100 \mu \mathrm{g} \mathrm{Fe} / \mathrm{mL}$ for 2 hours at $37^{\circ} \mathrm{C}$ with $5 \% \mathrm{CO}_{2}$ and $100 \%$ humid atmosphere in $2 \mathrm{~mL}$ DMEM or RPMI-1640, the MLECs and colon 26 cells were washed three times with PBS. The labeled MLECs and colon 26 cells were detached from the six-well plates using $0.05 \%$ trypsin, the same kind of cells within the six wells were collected in one group, and centrifuged at 1000 rpm for 10 minutes. After discarding the supernatants, cell pellets were fixed in $2.5 \%$ phosphate buffered glutaraldehyde for 4 hours at $4^{\circ} \mathrm{C}$, and then washed three times in PBS. The samples were dehydrated by a graded series of ethanol, stained in 1\% uranyl acetate and embedded in epon. Ultrathin sections (nm) were contrasted with $0.3 \%$ lead citrate and then examined and photographed at $80 \mathrm{kV}$ by TEM (H-7650; Hitachi Ltd). In order to make sure of the morphology of the nanoparticles, the LYVE-1-PEGUSPIO and PEG-USPIO nanoparticles suspension were diluted with PBS to a concentration of $10 \mu \mathrm{g} \mathrm{Fe} / \mathrm{mL}$, and was directly deposited onto a carbon-coated copper grid and air-dried at room temperature and examined and photographed by TEM.

\section{MRI of labeled cells and corresponding AAS}

To demonstrate the MRI detection efficiency of LYVE-1PEG-USPIO and PEG-USPIO nanoparticles, the MLECs and colon 26 cells were incubated separately in 24-well plates (BD Biosciences) at an amount of $1 \times 10^{5}$ cells $/ \mathrm{mL}$ each well for 16 hours at $37^{\circ} \mathrm{C}$ in a $5 \% \mathrm{CO}_{2}$ and $100 \%$ humid atmosphere, in $1 \mathrm{~mL}$ DMEM and RPMI-1640 respectively. Then, the growth media were discarded, serum-free DMEM or serum-free RPMI-1640 medium containing 6.25, 12.5, 25, 50,100 , or $200 \mu \mathrm{g} \mathrm{Fe} / \mathrm{mL}$ of either LYVE-1-PEG-USPIO or PEG-USPIO nanoparticles was added into each well in $1 \mathrm{~mL}$ for 2 hours at $37^{\circ} \mathrm{C}$ in a $5 \% \mathrm{CO}_{2}$ and $100 \%$ humid atmosphere. Unlabeled MLECs and colon 26 cells were used as control groups. Labeled and unlabeled MLECs and colon 26 cells were washed three times with PBS, and detached using $0.05 \%$ trypsin. Labeled cells $\left(1 \times 10^{5}\right.$ cells/tube $)$ cultured within various concentrations and unlabeled cells were centrifuged at $800 \mathrm{rpm}$ for 5 minutes, then the supernatant was discarded and the cells were resuspended with $0.25 \mathrm{~mL} 1 \%$ agarose gel in $0.25 \mathrm{~mL}$ Eppendorf tubes. In order to avoid interference produced by macroscopic external magnetic field B0 inhomogeneities, these tubes were embedded in a tank filled with $1 \%$ agarose gel. MRI was immediately performed by using a 3.0 T MRI scanner equipped with a small animal coil. Imaging was achieved by using the $\mathrm{T}_{2}$ spin echo sequence. The parameters were as follows: TR $=4000 \mathrm{~ms}$; $\mathrm{TE}=10,20,40,60,80$, and $100 \mathrm{~ms} ; \mathrm{FOV}=8 \times 8 \mathrm{~cm}^{2}$; matrix size $=256 \times 256$; slice thickness $=1 \mathrm{~mm} ; \mathrm{NEX}=3$. Source images analysis was made on a GE ADW4.4 workstation. $\mathrm{A}_{2}$ map program was used to calculate the sample $\mathrm{T}_{2}$ 
relaxation times. The $R_{2}$ was calculated as the inverse of the $\mathrm{T}_{2}$-relaxation time in seconds $\left(1 / \mathrm{T}_{2}\right)$. Each Eppendorf tube's axial section was measured at three ROIs $(3 \times 4$ pixels $)$ in at least three layers. When the MR test was finished, the iron content of labeled and unlabeled cells of each sample was measured with AAS.

\section{AAS quantification of labeled cells}

To determine the iron content of labeled and unlabeled cells, AAS measurement was performed. The experiment was performed three times. The average value of cell binding iron content was taken.

\section{Statistical analysis}

Statistical analysis was performed by using the SPSS 16.0 software (IBM Corporation, Armonk, NY, USA). All data were presented as mean \pm standard deviation (SD). Statistical significance was assessed by an unpaired Student's $t$-test for single comparisons or by one-way analysis of variance (ANOVA) for multiple comparisons. Pearson correlation analysis was run on comparisons of iron content and $\mathrm{R}_{2}$. A $P$-value of less than 0.05 was considered statistically significant.

\section{Results}

\section{Ligand selected}

The immunohistochemical staining results showed that the anti-podoplanin antibody expressed not only in the lymphatic vessels, but also in a large number of other cells within the Lewis tumor. However, anti-LYVE-1 antibody was mainly expressed in the lymphatic vessels (Figure 1A and B). Therefore, we concluded that the anti-LYVE-1 antibody was more specific than the anti-podoplanin antibody in the identification of lymphatic vessels within the mouse Lewis subcutaneous transplanted tumor, so we selected anti-LYVE-1 antibody as the specific ligand.
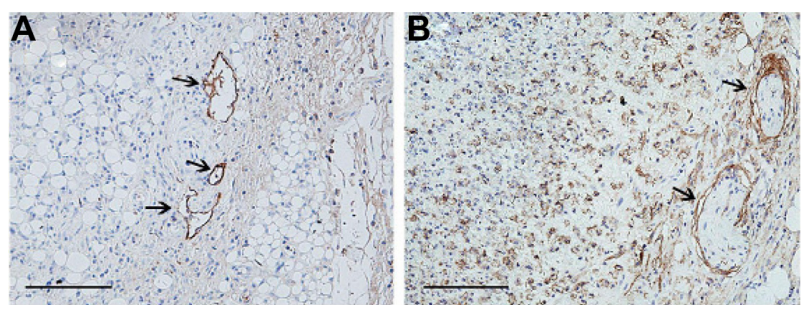

Figure I Immunohistochemical staining of Lewis tumor.

Notes: (A) LYVE-I-positive staining and (B) podoplanin-positive staining were seen in the Lewis tumor. Anti-podoplanin antibody could also stain a large number of other cells besides the lymphatic vessels (arrows), but anti-LYVE-I antibody identified mainly only lymphatic vessels (arrows). Bar $=100 \mu \mathrm{m}$

Abbreviation: LYVE-I, lymphatic vessel endothelial hyaluronan receptor-I.

\section{Nanoparticles characterization}

The results showed that the zeta potentials of PEG-USPIO and LYVE-1-PEG-USPIO nanoparticles were $2.57 \pm 0.83 \mathrm{mV}$ and $12.38 \pm 4.87 \mathrm{mV}$, respectively, and the $\mathrm{z}$-average HDs were $47.91 \pm 0.73 \mathrm{~nm}$ and $57.42 \pm 0.31 \mathrm{~nm}$, respectively. The $\mathrm{R}_{2}$ was plotted on the $y$-axis versus iron concentration ( $\mathrm{x}$-axis). The relaxivity of the nanoparticles was obtained by the slope of the linear regression of $\mathrm{R}_{2}$ with iron concentration. The relaxivity of the PEG-USPIO and LYVE-1-PEG-USPIO nanoparticles was $608.32 \mathrm{mM}^{-1} \mathrm{~s}^{-1}$ and $185.48 \mathrm{mM}^{-1} \mathrm{~s}^{-1}$, respectively (Figure $2 \mathrm{~A}$ and $\mathrm{B}$ ).

\section{Immunofluorescence microscopy}

Immunofluorescence results showed that LYVE-1 receptors were expressed in MLECs, but not in colon 26 cells (Figure 3A-D).

\section{Prussian blue staining and corresponding AAS}

Prussian blue staining was used to determine the existence of the nanoparticles in cells, and the cells binding nanoparticles were visualized as blue granules (Figure 4A-J). The number of blue granules increased with the increasing iron concentration, especially in the LYVE-1-PEG-USPIO labeled MLECs. To assess specific binding of LYVE-1-PEG-USPIO nanoparticles to MLECs, the iron content of the two cell lines was detected with AAS after 2 hours of incubation with LYVE-1-PEG-USPIO and PEG-USPIO. When the incubation concentrations of LYVE-1-PEG-USPIO and PEG-USPIO were $25 \mu \mathrm{g} \mathrm{Fe} / \mathrm{mL}$, we found the highest accumulation of LYVE-1-PEG-USPIO in the MLECs with the mean iron content of $48.4 \pm 8.5 \mathrm{pg} \mathrm{Fe} / \mathrm{cell}$. The mean iron contents of LYVE-1-PEG-USPIO labeled colon 26 cells, PEG-USPIO labeled MLECs, and PEG-USPIO labeled colon 26 cells were $19.92 \pm 3.58 \mathrm{pg} \mathrm{Fe} / \mathrm{cell}, 17.56 \pm 5.76 \mathrm{pg} \mathrm{Fe} / \mathrm{cell}$, and $15.61 \pm 7.23 \mathrm{pg} \mathrm{Fe} /$ cell, respectively. When increasing the incubation concentration of LYVE-1-PEG-USPIO and PEG-USPIO to $100 \mu \mathrm{g} \mathrm{Fe} / \mathrm{mL}$, the mean iron content of LYVE-1-PEG-USPIO labeled MLECs was still the highest (219.22 $\pm 14.89 \mathrm{pg} \mathrm{Fe} / \mathrm{cell})$, and approximate 4.6 times greater than the iron content of LYVE-1-PEG-USPIO labeled MLECs at the iron incubation concentration of $25 \mu \mathrm{g} \mathrm{Fe} /$ $\mathrm{mL}$. Although the colon 26 cells showed an intense binding of LYVE-1-PEG-USPIO, they only reached a mean iron contents of $64.41 \pm 6.39 \mathrm{pg} \mathrm{Fe} / \mathrm{cell}$. The mean iron contents of PEG-USPIO labeled MLECs and PEG-USPIO labeled colon 26 cells were $38.92 \pm 7.07 \mathrm{pg} \mathrm{Fe} / \mathrm{cell}$ and $35.03 \pm 9.89 \mathrm{pg} \mathrm{Fe} /$ cell respectively (Figure 5). 

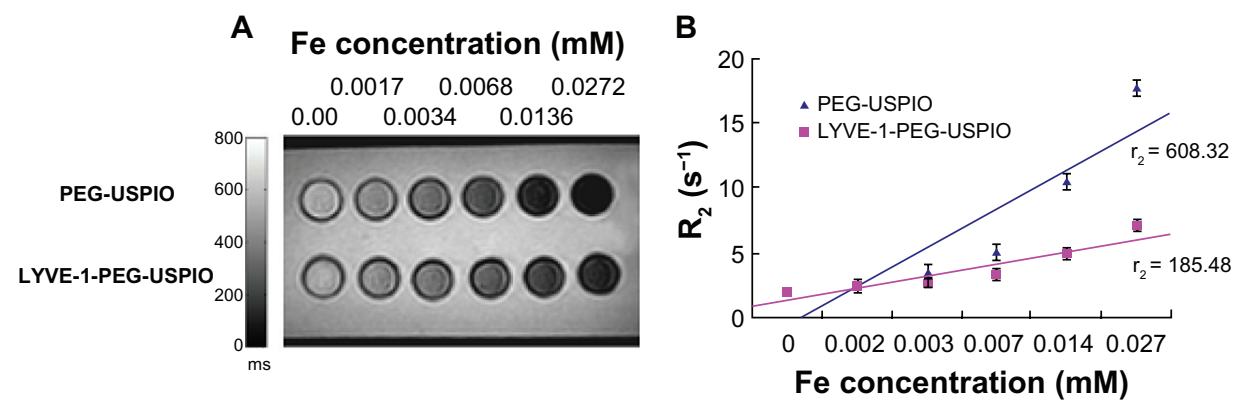

Figure 2 The relaxivity of the nanoparticles.

Notes: (A) $T_{2}$-weighted MR images of PEG-USPIO and LYVE-I-PEG-USPIO in agarose gel with various concentrations at $3.0 \mathrm{~T}$ MRI. (B) Graph of the $\mathrm{R}_{2}$ against the Fe concentration for PEG-USPIO and LYVE-I-PEG-USPIO. The relaxivity of PEG-USPIO was $608.32 \mathrm{mM}^{-1} \mathrm{~s}^{-1}$, the relaxivity of LYVE-I-PEG-USPIO was I85.48 mM-1 $\mathrm{s}^{-1}$.

Abbreviations: LYVE-I-PEG-USPIO, lymphatic vessel endothelial hyaluronan receptor-I binding polyethylene glycol-coated ultrasmall superparamagnetic iron oxide; MR, magnetic resonance; MRI, magnetic resonance imaging; PEG-USPIO, polyethylene glycol-coated ultrasmall superparamagnetic iron oxide.

\section{TEM of labeled cells}

TEM of the two cell lines after 2 hours of incubation with LYVE-1-PEG-USPIO (100 $\mu \mathrm{g} \mathrm{Fe} / \mathrm{mL})$ and PEGUSPIO $(100 \mu \mathrm{g} \mathrm{Fe} / \mathrm{mL})$ was used to study the subcellular localization of the two types of nanoparticles. Images of the LYVE-1-PEG-USPIO labeled MLECs revealed that the nanoparticles were mainly located in the cytoplasm endosomes, and a few nanoparticles were also attached to the cell membrane (Figure 6A). However, the PEGUSPIO nanoparticles were mainly attached to the MLEC membrane (Figure 6B). In the colon 26 cells, the LYVE-1PEG-USPIO and PEG-USPIO nanoparticles were mainly attached to the cell membrane (Figure 6C and D), but a few LYVE-1-PEG-USPIO nanoparticles were also found in the cytoplasm endosomes.
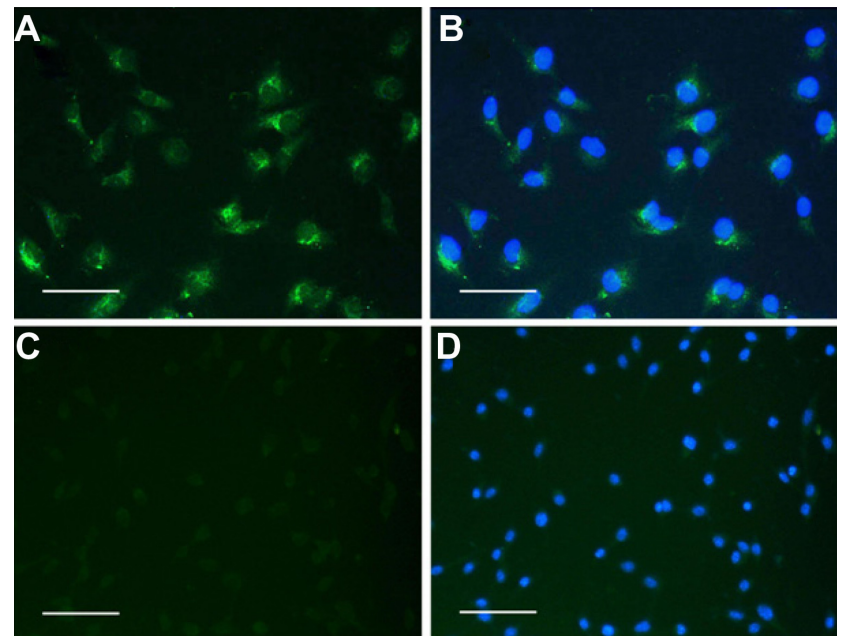

Figure 3 Immunofluorescence images of MLECs and colon 26 cells with antiLYVE-I antibody.

Notes: (A) LYVE-I receptors were positive for MLECs. (B) The merged images with DAPI staining of MLECs. (C) No LYVE-I receptor expressed in colon 26 cells. (D) The merged images with DAPI staining of colon 26 cells. Bar $=20 \mu \mathrm{m}$.

Abbreviations: DAPI, 4',6-diamidino-2-phenylindole; LYVE-I, lymphatic vessel endothelial hyaluronan receptor-I; MLECs, mouse lymphatic endothelial cells.

\section{$M R I$ and corresponding AAS in vitro}

Tubes containing MLECs and colon 26 cells, which were incubated with serial concentrations of LYVE-1-PEGUSPIO and PEG-USPIO, were scanned with an MRI $\mathrm{T}_{2}$ spin echo sequence. The signal intensity of $\mathrm{T}_{2}$-weighted images decreased with the increasing iron concentration (Figure 7A). The MRI results showed a concentrationdependent gradient for the four kinds of labeled cells (Figure 7B). As the incubation concentrations of LYVE1-PEG-USPIO and PEG-USPIO increased, the $\mathrm{R}_{2}$ of the labeled cells also increased. The $\mathrm{R}_{2}$ of tubes containing the same cell line incubated with LYVE-1-PEG-USPIO were higher than those incubated with PEG-USPIO at the same concentration. The $\mathrm{R}_{2}$ of tubes containing LYVE-1-PEGUSPIO labeled MLECs were higher than those containing LYVE-1-PEG-USPIO labeled colon 26 cells at the same concentration. The $\mathrm{R}_{2}$ of LYVE-1-PEG-USPIO labeled MLECs was significantly higher than other labeled cells at iron concentration of 25 to $200 \mu \mathrm{g} \mathrm{Fe} / \mathrm{mL}(P<0.05)$. There was no statistical difference in the $\mathrm{R}_{2}$ between the unlabeled MLECs and unlabeled colon 26 cell groups $(P>0.05)$. AAS results revealed a dose-dependent increase of nanoparticle labeled cells (Figure 7C). With increasing iron incubation concentration, the iron content of labeled cells increased. LYVE-1-PEG-USPIO labeled MLECs showed a significantly higher iron content than the other three kinds of labeled cells at the same incubation concentration. There was no statistical difference in the iron content between the unlabeled MLECs and unlabeled colon 26 cell groups $(P>0.05)$. The corresponding data were summarized in Table 1. Comparison of the $\mathrm{R}_{2}$ and iron content of labeled cells revealed significantly positive correlations. The Pearson correlation coefficient, $r$, for LYVE-1-PEG-USPIO labeled MLECs was $r=0.995(P<0.01)$, for PEG-USPIO labeled 


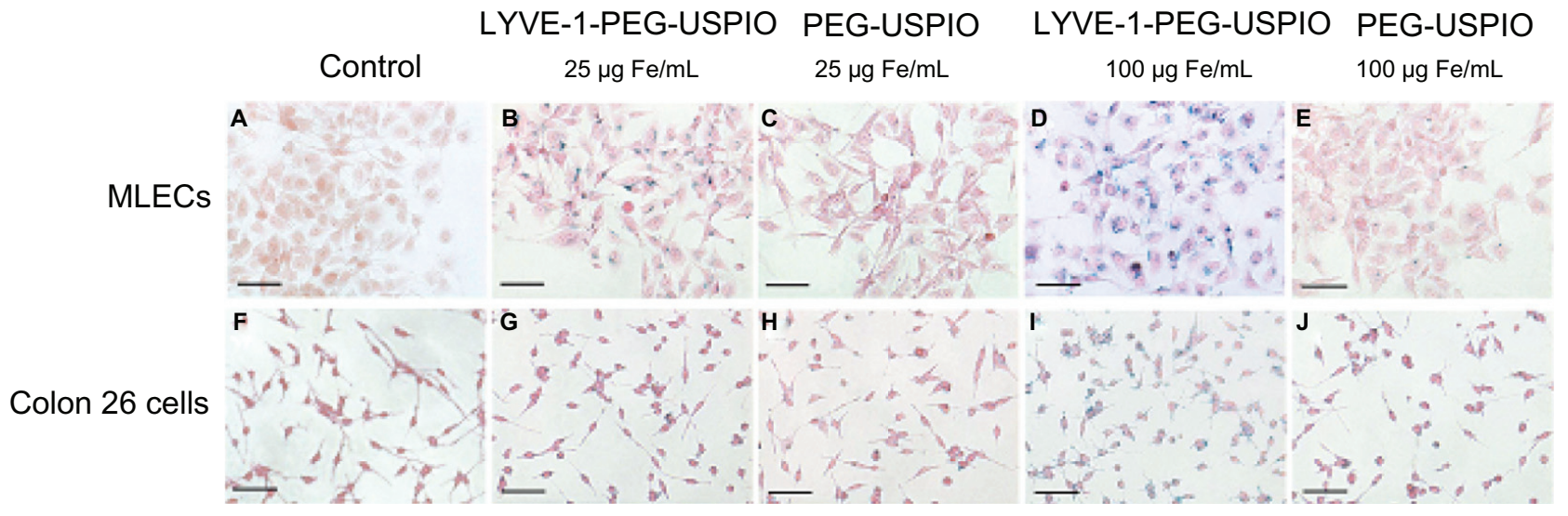

Figure 4 Prussian blue staining.

Notes: Prussian blue staining of labeled MLECs (B-E) and colon 26 cells (G-J) after incubation with LYVE-I-PEG-USPIO at $25 \mu \mathrm{g} \mathrm{Fe} / \mathrm{mL}$ (B and G) and I00 $\mu \mathrm{g}$ Fe/mL (D and I) and PEG-USPIO at $25 \mu \mathrm{g} \mathrm{Fe} / \mathrm{mL}(\mathbf{C}$ and $\mathbf{H})$ and $100 \mu \mathrm{g} \mathrm{Fe} / \mathrm{mL}(\mathbf{E}$ and $\mathbf{J})$ for 2 hours. Unlabeled MLECs $(\mathbf{A})$ and unlabeled colon 26 cells $(\mathbf{F})$ as control groups. Bar $=50 \mu \mathrm{m}$. Abbreviations: LYVE-I-PEG-USPIO, lymphatic vessel endothelial hyaluronan receptor-I binding polyethylene glycol-coated ultrasmall superparamagnetic iron oxide; MLECs, mouse lymphatic endothelial cells; PEG-USPIO, polyethylene glycol-coated ultrasmall superparamagnetic iron oxide.

MLECs was $\mathrm{r}=0.976(P<0.01)$, for LYVE-1-PEG-USPIO labeled colon 26 cells was $\mathrm{r}=0.997(P<0.01)$, and for PEG-USPIO labeled colon 26 cells was $\mathrm{r}=0.977(P<0.01)$ (Figure 7D).

\section{Discussion}

In this study, an MRI probe was conducted with the antiLYVE-1 monoclonal antibody, determined by the immunohistochemical staining of Lewis tumor specimens, as the specific targeting ligand and the PEG-coated USPIO nanoparticles as the signal ligand; the LYVE-1 receptor in LECs could be targeted and imaged by MRI. After evaluating the physical properties of this MRI probe, a series of cell experiments in vitro were performed to assess the specificity and effectiveness of the LYVE-1-PEG-USPIO nanoparticles.

To evaluate the $T_{2}$ enhancing capabilities of PEG-USPIO and LYVE-1-PEG-USPIO nanoparticles, agarose gel solutions ( $1 \%$ agarose gel) of the PEG-USPIO and LYVE-1-PEG-USPIO nanoparticles at different iron concentrations were imaged by an

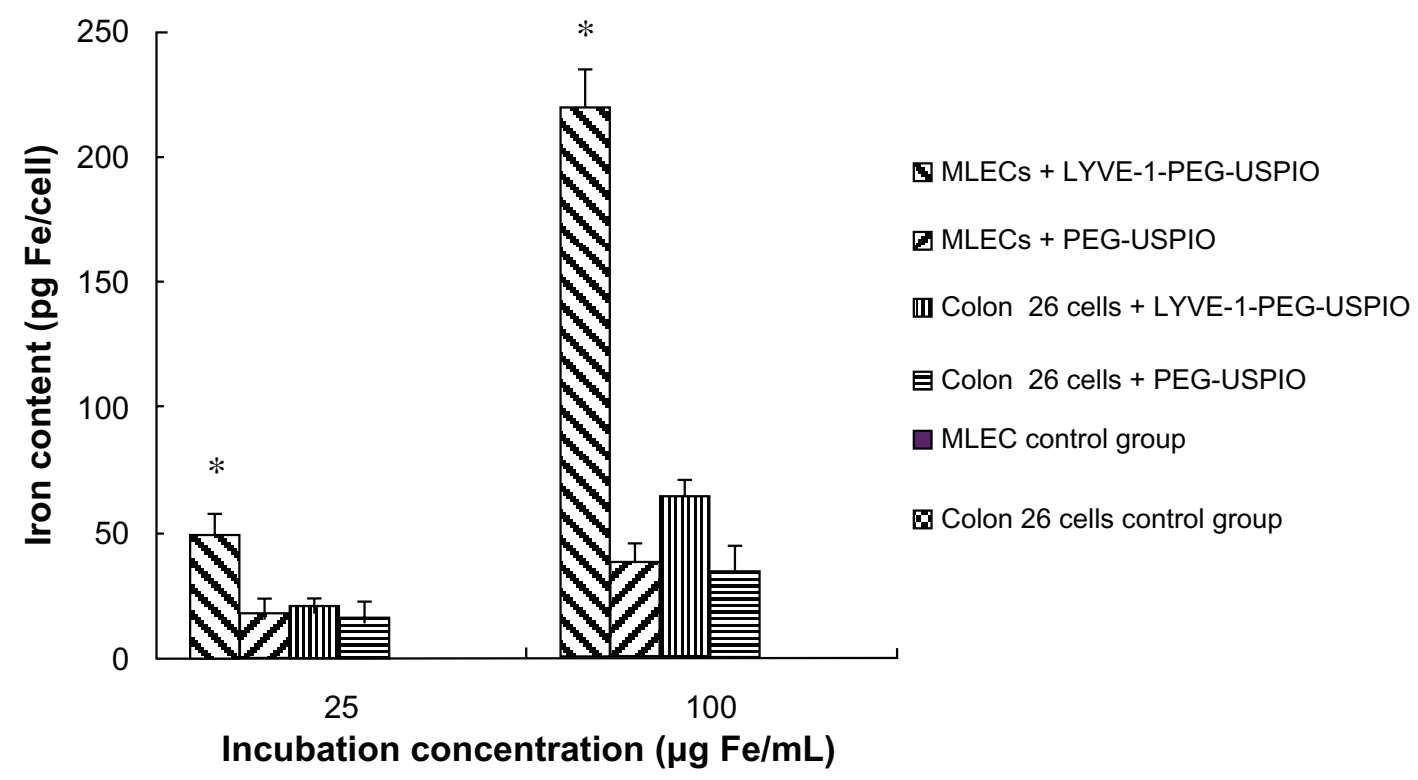

Figure 5 The results of AAS.

Notes: After Prussian blue staining, the higher binding of LYVE-I-PEG-USPIO was observed as compared with PEG-USPIO for two cell lines at the incubation concentration of $25 \mu \mathrm{g} \mathrm{Fe} / \mathrm{mL}$ and $100 \mu \mathrm{g} \mathrm{Fe} / \mathrm{mL}$, and highest binding of LYVE-I-PEG-USPIO was observed for MLECs. *P $<0.05$ MLECs with LYVE-I-PEG-USPIO versus colon 26 cells with LYVE-I-PEG-USPIO.

Abbreviations: AAS, atomic absorption spectroscopy; LYVE-I-PEG-USPIO, lymphatic vessel endothelial hyaluronan receptor-I binding polyethylene glycol-coated ultrasmall superparamagnetic iron oxide; MLECs, mouse lymphatic endothelial cells; PEG-USPIO, polyethylene glycol-coated ultrasmall superparamagnetic iron oxide. 


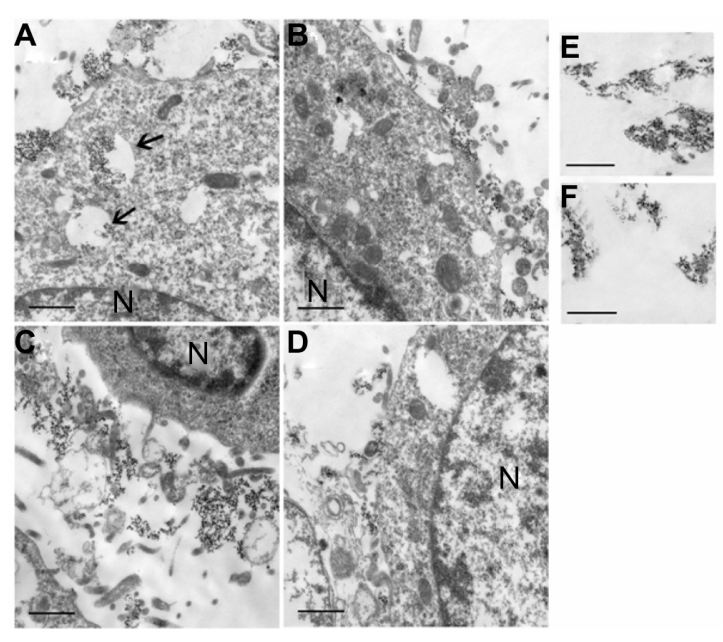

Figure 6 TEM images of LYVE-I-PEG-USPIO (A and $\mathbf{C}$ ) and PEG-USPIO (B and D) labeled MLECs (A and $\mathbf{B}$ ) and colon 26 cells (C and $\mathbf{D})$ at the concentration of $100 \mu \mathrm{g} \mathrm{Fe} / \mathrm{mL}$, and TEM images of LYVE-I-PEG-USPIO nanoparticles (E) and PEGUSPIO nanoparticles (F) in PBS (accelerated voltage, $80 \mathrm{kv}$ ).

Notes: Bar $=$ I $\mu \mathrm{m}$. $\mathrm{N}=$ nucleus. (A) The LYVE-I-PEG-USPIO nanoparticles were mainly located in the cytoplasm endosomes (thin arrows), and a few nanoparticles were attached to the cell membrane. (B) The PEG-USPIO nanoparticles were mainly attached to the MLEC membrane. (C) The LYVE-I-PEG-USPIO nanoparticles were mainly attached to the cell membrane. (D) The PEG-USPIO nanoparticles were mainly attached to the cell membrane. (E) The LYVE-I-PEG-USPIO nanoparticles in PBS. (F) The PEG-USPIO nanoparticles in PBS.

Abbreviations: LYVE-I-PEG-USPIO, lymphatic vessel endothelial hyaluronan receptor-I binding polyethylene glycol-coated ultrasmall superparamagnetic iron oxide; MLECs, mouse lymphatic endothelial cells; PBS, phosphate-buffered solution; PEG-USPIO, polyethylene glycol-coated ultrasmall superparamagnetic iron oxide; TEM, transmission electron microscopy.

$\mathrm{MRT}_{2}$ spin echo sequence. $\mathrm{T}_{2}$-weighted images showed that the signal intensity decreased as the iron concentration increased. The relaxivity of the two types of nanoparticles, an index of MR contrast agent used to indicate the effectiveness of these agents, was $608.32 \mathrm{mM}^{-1} \mathrm{~s}^{-1}$ for PEG-USPIO and $185.48 \mathrm{mM}^{-1} \mathrm{~s}^{-1}$ for LYVE-1-PEG-USPIO; both were much higher than that of the commercial MRI contrast agent Feridex $\left(127.48 \mathrm{mM}^{-1} \mathrm{~s}^{-1}\right){ }^{31}$ This indicated that the PEG-USPIO and LYVE-1-PEG-USPIO nanoparticles could generate contrast on $\mathrm{T}_{2}$-weighted imaging, and were promising contrast agents.

Prussian blue staining results indicated that the two types of cells had different binding capacities to the two types of nanoparticles, and this was further verified by AAS. AAS results of the same samples, which had been examined with Prussian blue staining, showed that with the concentration of LYVE-1-PEG-USPIO and PEG-USPIO nanoparticles increasing, the amount of nanoparticles bound to the two kinds of cells also increased. At a low concentration $(25 \mu \mathrm{g}$ $\mathrm{Fe} / \mathrm{mL}$ ), the iron content of the LYVE-1-PEG-USPIO labeled MLECs was significantly higher than the other three kinds of labeled cells and control group cells $(P<0.05)$, but there were no statistical differences among the PEG-USPIO labeled MLECs, LYVE-1-PEG-USPIO labeled colon 26 cells, and
PEG-USPIO labeled colon 26 cells. When increasing the incubation concentration of LYVE-1-PEG-USPIO and PEGUSPIO to $100 \mu \mathrm{g} \mathrm{Fe} / \mathrm{mL}$, the iron content of the LYVE-1PEG-USPIO labeled MLECs which were harvested after the Prussian blue staining, increased most significantly, approximate 4.6 times greater than the iron content of the LYVE-1-PEG-USPIO labeled MLECs at the iron incubation concentration of $25 \mu \mathrm{g} \mathrm{Fe} / \mathrm{mL}$. Although the iron content of the other three kinds of labeled cells also increased when increasing iron incubation concentration, they were far below that of the LYVE-1-PEG-USPIO labeled MLECs.

MRI detection of the labeled cells showed the same trend as the results of the Prussian blue staining. The signal intensity of the LYVE-1-PEG-USPIO labeled MLECs decayed most rapidly when the iron concentration increased, and AAS results of the same samples, which had been examined by MRI also showed the highest iron content of LYVE-1-PEG-USPIO labeled MLECs (Figure 7). The iron content of the LYVE-1PEG-USPIO labeled MLECs was approximately 2.3 times greater than the iron content of the LYVE-1-PEG-USPIO labeled colon 26 cells at the iron incubation concentration of $25 \mu \mathrm{g} \mathrm{Fe} / \mathrm{mL}$, and approximately 4.4 times greater at the iron incubation concentration of $200 \mu \mathrm{g} \mathrm{Fe} / \mathrm{mL}$.

As we know, the binding capacity of cells to nanoparticles might be attributed to receptor-mediated endocytosis, nanoparticles' surface charge, and size. To analyze the different effects caused by the three factors, we chose colon 26 cells, which lack LYVE-1 receptor as confirmed by the immunofluorescence study, as the negative control under the uniform conditions of temperature, incubation concentration, and incubation time.

The mean hydrodynamic size of the LYVE-1-PEG-USPIO nanoparticles was $57.42 \pm 0.31 \mathrm{~nm}$, which was bigger than that of the PEG-USPIO nanoparticles (47.91 $\pm 0.73 \mathrm{~nm})$. It had been reported that particles with radii $<50 \mathrm{~nm}$ exhibited significantly greater uptake compared with particles $>50 \mathrm{~nm} \cdot{ }^{32,33}$ Theoretically, without considering the effect of LYVE-1 receptor-mediated endocytosis and the nanoparticles' surface charge, the number of cells binding PEG-USPIO nanoparticles would be much greater than the number of cells binding LYVE1-PEG-USPIO nanoparticles at the same incubation time and at the same iron incubation concentration. However, for the two cell lines, the higher cell binding nanoparticle was LYVE1-PEG-USPIO, not PEG-USPIO; this indicated that the size of the nanoparticles was not the major factor for the binding capacity of cells to the two types of nanoparticles.

The mean zeta potential of the two types of nanoparticles measured with a laser particle analyzer was $2.57 \pm 0.83 \mathrm{mV}$ 

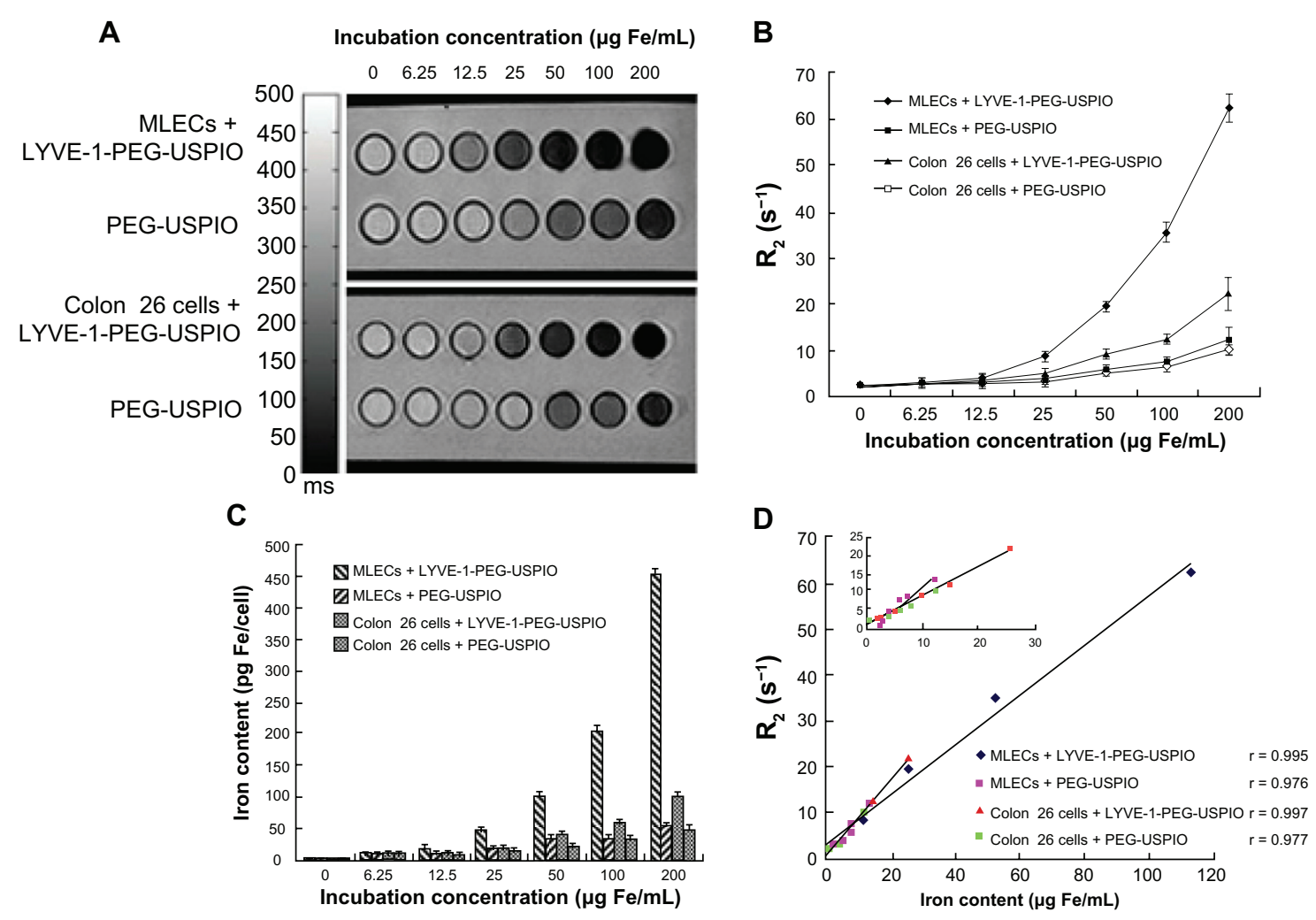

Figure 7

Notes: (A) T2-weighted MR images of MLECs and colon 26 cells incubated with LYVE-I- PEG-USPIO and PEG-USPIO nanoparticles at different concentrations for 2 hours. (B) Different relaxation rates of MLECs and colon 26 cells incubated with increasing iron concentrations of LYVE-I-PEG-USPIO and PEG-USPIO nanoparticles. The graph indicated the increasing $R_{2}$ at higher LYVE-I-PEG-USPIO and PEG-USPIO concentrations of MLECs and colon 26 cells. The $R_{2}$ of LYVE-I-PEG-USPIO labeled MLECs was significantly higher than the other three kinds of labeled cells at iron concentrations of 25 to $200 \mu \mathrm{g} \mathrm{Fe} / \mathrm{mL}$. (C) Iron content (pg Fe/cell) of LYVE-I-PEG-USPIO and PEGUSPIO labeled MLECs and colon 26 cells was determined by AAS after incubation with different concentrations of nanoparticles for 2 hours. Higher cell binding iron content was observed for LYVE-I-PEG-USPIO than PEG-USPIO in two cell lines. Highest binding was found in LYVE-I-PEG-USPIO labeled MLECs. (D) Comparison of MR relaxation rate, $R_{2}$, and iron content of LYVE-I-PEG-USPIO labeled MLECs, PEG-USPIO labeled MLECs, LYVE-I-PEG-USPIO labeled colon 26 cells, and PEG-USPIO labeled colon 26 cells revealed significantly positive correlations.

Abbreviations: LYVE-I-PEG-USPIO, lymphatic vessel endothelial hyaluronan receptor-I binding polyethylene glycol-coated ultrasmall superparamagnetic iron oxide; MLECs, mouse lymphatic endothelial cells; MR, magnetic resonance; PEG-USPIO, polyethylene glycol-coated ultrasmall superparamagnetic iron oxide.

for PEG-USPIO and $12.38 \pm 4.87 \mathrm{mV}$ for LYVE-1-PEGUSPIO. Studies had shown that the cell phagocytosis rate of surface-positively charged nanoparticles was faster than that of neutral or surface-negatively charged nanoparticles, ${ }^{34-36}$ because nanoparticles with positive surface charges could more easily adhere to the surface-negatively charged cell membrane by electrostatic interactions. ${ }^{37}$ The AAS results showed that the iron content of LYVE-1-PEGUSPIO labeled colon 26 cells was approximately 1.3 times greater than that of PEG-USPIO labeled colon 26 cells at the iron incubation concentration of $25 \mu \mathrm{g} \mathrm{Fe} / \mathrm{mL}$, and the differences gradually increased as the iron incubation concentration increased. The iron content of LYVE-1PEG-USPIO labeled colon 26 cells was approximately 2.1 times greater than that of PEG-USPIO labeled colon 26 cells at the incubation concentration of $200 \mu \mathrm{g} \mathrm{Fe} / \mathrm{mL}$. Thus, we concluded that the different binding capacities of colon 26 cells to LYVE-1-PEG-USPIO and PEG-USPIO nanoparticles were mainly caused by the different surface charges of the two types of nanoparticles. However, for the binding capacities of MLECs to the two types of nanoparticles, the iron content of LYVE-1-PEG-USPIO labeled MLECs was approximately 2.6 times greater than that of PEG-USPIO labeled MLECs at the iron incubation concentration of $25 \mu \mathrm{g} \mathrm{Fe} / \mathrm{mL}$, and increased to 8.5 times greater at the iron incubation concentration of $200 \mu \mathrm{g} \mathrm{Fe} /$ $\mathrm{mL}$. Furthermore, the iron content of LYVE-1-PEG-USPIO labeled MLECs was approximately 2.3 times greater than the iron content of the LYVE-1-PEG-USPIO labeled colon 26 cells at the iron incubation concentration of $25 \mu \mathrm{g} \mathrm{Fe} /$ $\mathrm{mL}$, and approximately 4.4 times greater at the iron incubation concentration of $200 \mu \mathrm{g} \mathrm{Fe} / \mathrm{mL}$. These data indicated that the MLEC binding capacity to LYVE-1-PEG-USPIO nanoparticles was considerably higher than that of the colon 26 cells. This should be attributed to not only the different surface charges of the two types of nanoparticles, but also 
Table I Iron content and $R_{2}$ of MLECs and colon 26 cells after incubation with LYVE-I-PEG-USPIO and PEG-USPIO at various concentrations for 2 hours

\begin{tabular}{|c|c|c|c|}
\hline $\begin{array}{l}\text { Incubation concentration } \\
(\mu \mathrm{g} \mathrm{Fe} / \mathrm{mL})\end{array}$ & Nanoparticle labeled cells & $\begin{array}{l}\text { AAS } \\
\text { Iron content (pg Fe/cell) }\end{array}$ & $\begin{array}{l}\text { MR imaging } \\
\mathbf{R}_{2}\left(\mathbf{s}^{-1}\right)\end{array}$ \\
\hline \multirow[t]{4}{*}{0} & MLEC + LYVE-I-PEG-USPIO & $0.93 \pm 0.23$ & $2.12 \pm 0.21$ \\
\hline & MLEC + PEG-USPIO & $0.95 \pm 0.32$ & $2.32 \pm 0.19$ \\
\hline & Colon 26 + LYVE-I-PEG-USPIO & $0.87 \pm 0.39$ & $2.24 \pm 0.23$ \\
\hline & Colon 26 + PEG-USPIO & $0.88 \pm 0.50$ & $2.15 \pm 0.25$ \\
\hline \multirow[t]{4}{*}{6.25} & MLEC + LYVE-I-PEG-USPIO & $9.32 \pm 1.36$ & $2.92 \pm 0.23$ \\
\hline & MLEC + PEG-USPIO & $8.16 \pm 1.12$ & $2.63 \pm 0.21$ \\
\hline & Colon 26 + LYVE-I-PEG-USPIO & $7.64 \pm 1.21$ & $2.67 \pm 0.34$ \\
\hline & Colon 26 + PEG-USPIO & $7.44 \pm 1.15$ & $2.43 \pm 0.28$ \\
\hline \multirow[t]{4}{*}{12.5} & MLEC + LYVE-I-PEG-USPIO & $17.52 \pm 2.12$ & $3.90 \pm 0.57$ \\
\hline & MLEC + PEG-USPIO & $8.92 \pm 1.08$ & $2.71 \pm 0.46$ \\
\hline & Colon 26 + LYVE-I-PEG-USPIO & $10.23 \pm 1.42$ & $3.03 \pm 0.59$ \\
\hline & Colon 26 + PEG-USPIO & $8.64 \pm 1.28$ & $2.54 \pm 0.35$ \\
\hline \multirow[t]{4}{*}{25} & MLEC + LYVE-I-PEG-USPIO & $46.04 \pm 3.12$ & $8.52 \pm 0.34$ \\
\hline & MLEC + PEG-USPIO & $18.16 \pm 2.04$ & $3.71 \pm 0.24$ \\
\hline & Colon 26 + LYVE-I-PEG-USPIO & $19.84 \pm 2.16$ & $4.85 \pm 0.29$ \\
\hline & Colon 26 + PEG-USPIO & $15.56 \pm 1.36$ & $2.97 \pm 0.38$ \\
\hline \multirow[t]{4}{*}{50} & MLEC + LYVE-I-PEG-USPIO & $101.64 \pm 4.24$ & $19.43 \pm 0.87$ \\
\hline & MLEC + PEG-USPIO & $30.36 \pm 2.72$ & $5.72 \pm 0.79$ \\
\hline & Colon 26 + LYVE-I-PEG-USPIO & $39.12 \pm 2.44$ & $9.18 \pm 0.75$ \\
\hline & Colon 26 + PEG-USPIO & $22.92 \pm 1.96$ & $4.94 \pm 0.86$ \\
\hline \multirow[t]{4}{*}{100} & MLEC + LYVE-I-PEG-USPIO & $208.24 \pm 7.04$ & $35.21 \pm 1.98$ \\
\hline & MLEC + PEG-USPIO & $35.24 \pm 3.92$ & $7.26 \pm 0.89$ \\
\hline & Colon 26 + LYVE-I-PEG-USPIO & $58.80 \pm 4.28$ & $12.36 \pm 1.21$ \\
\hline & Colon 26 + PEG-USPIO & $31.64 \pm 2.92$ & $6.32 \pm 0.98$ \\
\hline \multirow[t]{4}{*}{200} & MLEC + LYVE-I-PEG-USPIO & $452.80 \pm 12.48$ & $62.50 \pm 3.06$ \\
\hline & MLEC + PEG-USPIO & $53.61 \pm 4.32$ & $12.11 \pm 2.42$ \\
\hline & Colon 26 + LYVE-I-PEG-USPIO & $101.92 \pm 5.40$ & $22.33 \pm 3.38$ \\
\hline & Colon 26 + PEG-USPIO & $47.96 \pm 3.44$ & $10.35 \pm 1.56$ \\
\hline
\end{tabular}

Note: Results expressed as mean \pm standard deviations $(n=3)$.

Abbreviations: AAS, atomic absorption spectrometry; LYVE-I-PEG-USPIO, lymphatic vessel endothelial hyaluronan receptor-I binding polyethylene glycol-coated ultrasmall superparamagnetic iron oxide; MLECs, mouse lymphatic endothelial cells; MR, magnetic resonance; PEG-USPIO, polyethylene glycol-coated ultrasmall superparamagnetic iron oxide.

receptor-mediated endocytosis, and the latter should be considered as the major factor.

In addition, the diameters of the two cell lines used in this study were different; MLEC diameters were bigger than colon 26 cell diameters, so the surface area of a single MLEC was bigger than that of a single colon 26 cell. In the condition of the same number of the two kinds of cells, the total surface area of the MLECs was much bigger than that of the colon 26 cells. The results of the AAS analysis showed that there was no statistical difference between the iron content of the PEG-USPIO labeled MLECs and PEG-USPIO labeled colon 26 cells $(P>0.05)$.

TEM results indicated that the localizations of LYVE-1PEG-USPIO and PEG-USPIO nanoparticles in MLECs and colon 26 cells were different at the iron incubation concentration of $100 \mu \mathrm{g} \mathrm{Fe} / \mathrm{mL}$ for 2 hours. For colon 26 cells, the
LYVE-1-PEG-USPIO nanoparticles were mainly attached to the cell membrane, and a few were located in colon 26 cell cytoplasmic endosomes. The PEG-USPIO nanoparticles were almost all attached to the membranes of MLECs and colon 26 cells (Figure 6). Researchers found that the uptake of USPIO by cells was dose and time dependent. ${ }^{38,39}$ Sun et al reported that only a few cells showed the uptake of USPIO $(0.3 \mu \mathrm{mol} \mathrm{Fe} / \mathrm{mL})$ after incubation for 20 minutes, and the uptake of USPIO gradually increased during the next 12 hours. ${ }^{38}$ In our study, TEM of labeled cells was performed at the iron incubation concentration of $100 \mu \mathrm{g} \mathrm{Fe} / \mathrm{mL}$ for 2 hours. The PEG-USPIO nanoparticles were almost all attached to the cell membrane; we thought the PEG with which the USPIO nanoparticles were modified could reduce the nonspecific phagocytosis, and another reason might be the insufficient incubation time. We thought that with 
prolonged incubation time and increased iron incubation concentration, the iron content of the labeled cells could have certain changes, which need further study. However, the LYVE-1-PEG-USPIO nanoparticles were mainly located in the MLECs cytoplasmic endosomes, with a few attached to the cell membranes. This should be attributed to receptormediated endocytosis. Researchers pointed out that, there were at least three types of endocytosis for nanoparticles: clathrin-mediated endocytosis, caveolae-mediated endocytosis, and clathrin-and caveolao-independent endocytosis. ${ }^{40}$ Prevo et al showed that LYVE-1 could mediate the endocytosis of hyaluronic acid by means of receptor-mediated endocytosis, and they inferred that LYVE-1 mediated the uptake of hyaluronic acid via caveolae-mediated endocytosis. ${ }^{41}$ Therefore, it could be concluded that the LYVE-1-PEG-USPIO nanoparticles located in the MLEC cytoplasmic endosomes were mainly caused by receptor-mediated endocytosis.

We also found that the correlation of the $\mathrm{R}_{2}$ and the iron content of labeled cells as measured by AAS was significantly positive $(P<0.05)$. There was no significant difference among the $\mathrm{R}_{2}$ of the four kinds of labeled cells when the iron incubation concentration of nanoparticles was lower than $25 \mu \mathrm{g} \mathrm{Fe} / \mathrm{mL}(P>0.05)$. However, when the iron incubation concentration was equal to or greater than $25 \mu \mathrm{g}$ $\mathrm{Fe} / \mathrm{mL}$, the differences were significant $(P<0.05)$, and the differences were more apparent with the increasing of the iron incubation concentration. Therefore, the iron concentration ( $\geq 25 \mu \mathrm{g} \mathrm{Fe} / \mathrm{mL}$ ) of the nanoparticles could be used in an in vivo test.

Our study had several limitations. First, due to the different LEC sources and species, the expression of LYVE-1 receptors in LECs might be different. Our study could not demonstrate that the anti-LYVE-1 antibody-based probe could be applied to other species, especially to human LECs, so the feasibility of the application of the probe in other sources and species of LECs needs further research. Second, Nakao et al have reported that not all LECs express LYVE-1 and the expression of LYVE-1 would be downregulated with cells or species aging. ${ }^{42}$ Although the cultured MLECs were controlled in three to nine generations in our study, as the MLEC generation increases, there might be some changes in the expression of LYVE-1. Our in vitro study demonstrated that the LYVE-1-PEG-USPIO nanoparticles could effectively target to MLECs; however, we did not perform an in-depth study about the influence of different cultured MLEC generations on the expression of LYVE-1. Third, it has been indicated that, until now, none of the LEC-associated molecular markers is entirely specific for lymphatic endothelium; LYVE-1 is also expressed in liver blood sinusoids, spleen endothelium, and activated tissue macrophages. When the LYVE-1-PEGUSPIO is applied in vivo, it is hard to avoid being captured by these cells, which may disturb the probe to the real targets. How to solve these problems requires further research.

\section{Conclusion}

This study indicated that the anti-mouse LYVE-1 antibodybased probe had good binding affinity to LYVE-1 expressed in MLECs. The MRI results indicated that the LYVE-1-PEGUSPIO nanoparticles could generate contrast on $\mathrm{T}_{2}$-weighted imaging, and the correlation between $\mathrm{R}_{2}$ and the iron content of labeled cells was significantly positive. The LYVE-1-PEGUSPIO nanoparticle was a promising agent for MRI of MLECs in vitro. Whether or not this probe could be used in the complex environment of the living organism needs further research.

\section{Acknowledgments}

The authors would like to thank the Institute of Chemistry, Chinese Academy of Sciences for their assistance with the synthesis of the nanoparticles. We would also like to thank the Key Laboratory of Imaging Diagnosis and Interventional Radiology of Liaoning Province for the related equipment and technical support. This work was supported by a grant from the Natural Science Foundation of China (30970810) to Yi Liu and the Foundation of Science and Technology Department of Liaoning Province, People's Republic of China (20081054) to Yi Liu.

\section{Disclosure}

The authors report no conflicts of interest in this work.

\section{References}

1. Aukland K, Reed RK. Interstitial-lymphatic mechanisms in the control of extracellular fluid volume. Physiol Rev. 1993;73(1):1-78.

2. Aukland K, Nicolaysen G. Interstitial fluid volume: local regulatory mechanisms. Physiol Rev. 1981;61(3):556-643.

3. Yun SJ, Gimotty PA, Hwang WT, et al. High lymphatic vessel density and lymphatic invasion underlie the adverse prognostic effect of radial growth phase regression in melanoma. Am J Surg Pathol. 2011;35(2): 235-242.

4. Coşkun U, Akyürek N, Dursun A, Yamaç D. Peritumoral lymphatic microvessel density associated with tumor progression and poor prognosis in gastric carcinoma. J Surg Res. 2010;164(1):110-115.

5. Kuroda K, Horiguchi A, Asano T, Asano T, Hayakawa M. Prediction of lymphatic invasion by peritumoral lymphatic vessel density in prostate biopsy cores. Prostate. 2008;68(10):1057-1063.

6. Saban MR, Towner R, Smith N, et al. Lymphatic vessel density and function in experimental bladder cancer. BMC Cancer. 2007; 7:219

7. Breiteneder-Geleff S, Soleiman A, Kowalski H, et al. Angiosarcomas express mixed endothelial phenotypes of blood and lymphatic capillaries: podoplanin as a specific marker for lymphatic endothelium. Am J Pathol. 1999; 154(2):385-394. 
8. Banerji S, Ni J, Wang SX, et al. LYVE-1, a new homologue of the CD44 glycoprotein, is a lymph-specific receptor for hyaluronan. $J$ Cell Biol. 1999;144(4):789-801.

9. Wigle JT, Oliver G. Prox1 function is required for the development of the murine lymphatic system. Cell. 1999;98(6):769-778.

10. Issa A, Le TX, Shoushtari AN, Shields JD, Swartz MA. Vascular endothelial growth factor-C and C-C chemokine receptor 7 in tumor cell-lymphatic cross-talk promote invasive phenotype. Cancer Res. 2009;69(1):349-357.

11. Laakkonen P, Waltari M, Holopainen T, et al. Vascular endothelial growth factor receptor 3 is involved in tumor angiogenesis and growth. Cancer Res. 2007;67(2):593-599.

12. Petrova TV, Bono P, Holnthoner W, et al. VEGFR-3 expression is restricted to blood and lymphatic vessels in solid tumors. Cancer Cell. 2008;13(6):554-556.

13. Weissleder R, Mahmood U. Molecular imaging. Radiology. 2001;219(2):316-333.

14. Cho EJ, Yang J, Mohamedali KA, et al. Sensitive angiogenesis imaging of orthotopic bladder tumors in mice using a selective magnetic resonance imaging contrast agent containing VEGF121/rGel. Invest Radiol. 2011;46(7):441-449.

15. Radermacher KA, Beghein N, Boutry S, et al. In vivo detection of inflammation using pegylated iron oxide particles targeted at E-selectin: a multimodal approach using MR imaging and EPR spectroscopy. Invest Radiol. 2009;44(7):398-404.

16. Weissleder R, Elizondo G, Wittenberg J, Rabito CA, Bengele HH, Josephson L. Ultrasmall superparamagnetic iron oxide: characterization of a new class of contrast agents for MR imaging. Radiology. 1990;175(2):489-493.

17. Zhang Y, Kohler N, Zhang M. Surface modification of superparamagnetic magnetite nanoparticles and their intracellular uptake. Biomaterials. 2002;23(7):1553-1561.

18. Gröger M, Loewe R, Holnthoner W, et al. IL-3 induces expression of lymphatic markers Prox-1 and podoplanin in human endothelial cells. J Immunol. 2004;173(12):7161-7169.

19. Hong YK, Harvey N, Noh YH, et al. Prox1 is a master control gene in the program specifying lymphatic endothelial cell fate. Dev Dyn. 2002;225(3):351-357.

20. Petrova TV, Mäkinen T, Mäkelä TP, et al. Lymphatic endothelial reprogramming of vascular endothelial cells by the Prox-1 homeobox transcription factor. EMBO J. 2002;21(17):4593-4599.

21. Partanen TA, Arola J, Saaristo A, et al. VEGF-C and VEGF-D expression in neuroendocrine cells and their receptor, VEGFR-3, in fenestrated blood vessels in human tissues. FASEB J. 2000;14(13):2087-2096.

22. Akishima $Y$, Ito $\mathrm{K}$, Zhang L, et al. Immunohistochemical detection of human small lymphatic vessels under normal and pathological conditions using the LYVE-1 antibody. Virchows Arch. 2004;444(2):153-157.

23. Jackson DG. The lymphatics revisited: new perspectives from the hyaluronan receptor LYVE-1. Trends Cardiovasc Med. 2003;13(1): $1-7$.

24. Mouta Carreira C, Nasser SM, di Tomaso E, et al. LYVE-1 is not restricted to the lymph vessels: expression in normal liver blood sinusoids and down-regulation in human liver cancer and cirrhosis. Cancer Res. 2001;61(22):8079-8084.

25. Wróbel T, Dziegiel P, Mazur G, Zabel M, Kuliczkowski K, Szuba A. LYVE-1 expression on high endothelial venules (HEVs) of lymph nodes. Lymphology. 2005;38(3):107-110.

International Journal of Nanomedicine

\section{Publish your work in this journal}

The International Journal of Nanomedicine is an international, peerreviewed journal focusing on the application of nanotechnology in diagnostics, therapeutics, and drug delivery systems throughout the biomedical field. This journal is indexed on PubMed Central, MedLine, CAS, SciSearch ${ }^{\circledR}$, Current Contents ${ }^{\circledR} /$ Clinical Medicine,
26. Schacht V, Dadras SS, Johnson LA, Jackson DG, Hong YK, Detmar M. Up-regulation of the lymphatic marker podoplanin, a mucin-type transmembrane glycoprotein, in human squamous cell carcinomas and germ cell tumors. Am J Pathol. 2005;166(3):913-921.

27. Kaji C, Tomooka M, Kato Y, Kojima H, Sawa Y. The expression of podoplanin and classic cadherins in the mouse brain. J Anat. 2012;220(5):435-446.

28. Breiteneder-Geleff S, Matsui K, Soleiman A, et al. Podoplanin, novel 43-kd membrane protein of glomerular epithelial cells, is down-regulated in puromycin nephrosis. Am J Pathol. 1997;151(4):1141-1152.

29. Rishi AK, Joyce-Brady M, Fisher J, et al. Cloning, characterization, and development expression of a rat lung alveolar type I cell gene in embryonic endodermal and neural derivatives. Dev Biol. 1995;167(1): 294-306.

30. Florez-Vargas A, Vargas SO, Debelenko LV, et al. Comparative analysis of D2-40 and LYVE-1 immunostaining in lymphatic malformations. Lymphology. 2008;41(3):103-110.

31. Huang J, Bu L, Xie J, et al. Effects of nanoparticle size on cellular uptake and liver MRI with polyvinylpyrrolidone-coated iron oxide nanoparticles. ACS Nano. 2010;4(12):7151-7160.

32. Desai MP, Labhasetwar V, Walter E, Levy RJ, Amidon GL. The mechanism of uptake of biodegradable microparticles in Caco-2 cells is size dependent. Pharm Res. 1997;14(11):1568-1573.

33. Prabha S, Zhou WZ, Panyam J, Labhasetwar V. Size-dependency of nanoparticle-mediated gene transfection: studies with fractionated nanoparticles. Int J Pharm. 2002;244(1-2):105-115.

34. Zahr AS, Davis CA, Rishko MV. Macrophage uptake of core-shell nanoparticles surface modified with poly (ethylene glycol). Langmuir. 2006;22(19):8178-8185.

35. Chung TH, Wu SH, Yao M, et al. The effect of surface charge on the uptake and biological function of mesoporous silica nanoparticles in 3T3-L1 cells and human mesenchymal stem cells. Biomaterials. 2007;28(19):2959-2966.

36. Tan K, Cheang P, Ho IA, Lam PY, Hui KM. Nanosized bioceramic particles could function as efficient gene delivery vehicles with target specificity for the spleen. Gene Ther. 2007;14(10):828-835.

37. Karaman DS, Desai D, Senthilkumar R, et al. Shape engineering vs organic modification of inorganic nanoparticles as a tool for enhancing cellular internalization. Nanoscale Res Lett. 2012;7(1):358.

38. Sun R, Dittrich J, Le-Huu M, et al. Physical and biological characterization of superparamagnetic iron oxide- and ultrasmall superparamagnetic iron oxide-labeled cells: a comparison. Invest Radiol. 2005;40(8): 504-513.

39. Kenzaoui BH, Vilá MR, Miquel JM, et al. Evaluation of uptake and transport of cationic and anionic ultrasmall iron oxide nanoparticles by human colon cells. Int J Nanomedicine. 2012;7:1275-1286.

40. Conner SD, Schmid SL. Regulated portals of entry into the cell. Nature. 2003;422(6927):37-44.

41. Prevo R, Banerji S, Ferguson DJ, Clasper S, Jackson DG. Mouse LYVE-1 is an endocytic receptor for hyaluronan in lymphatic endothelium. $J$ Biol Chem. 2001;276(22):19420-19430.

42. Nakao S, Zandi S, Faez S, Kohno R, Hafezi-Moghadam A. Discontinuous LYVE-1 expression in corneal limbal lymphatics: dual function as microvalves and immunological hot spots. FASEB $J$. 2012;26(2):808-817.

\footnotetext{
Submit your manuscript here: http://www.dovepress.com/international-journal-of-nanomedicine-journal
}

Journal Citation Reports/Science Edition, EMBase, Scopus and the Elsevier Bibliographic databases. The manuscript management system is completely online and includes a very quick and fair peer-review system, which is all easy to use. Visit http://www.dovepress.com/ testimonials.php to read real quotes from published authors. 